4 gallons of water. "The Black Leaf Extract of Tobacco" proved equally successful when used at the rate of 1 gallon to 65 gallons of cold water.

If the kerosene emulsion or other commercial oil emulsions are used, it should be with the usual precautions. Complete emulsification and known percentage of oil are essential. The above strengths of emulsion gave no injury used in the manner described. No practical benefit was secured, so far as the green peach aphis is concerned, from the use of orchard-boiled or commercial lime-sulphur washes, applied late in the spring just before the buds open. All spring prunings of the peach twigs should be gathered up and burned to prevent the aphis eggs harbored upon them from hatching and the lice crawling back upon the tree.

[Mr. Headlee's paper on Diabrotica vittata, together with the discussion thereupon, has been held till the next issue, owing to delay in submitting the manuscript.-E. P. F.]

The following paper was presented:

\title{
A KEY SUGGESTED FOR THE CLASSIFICATION OF EN- TOMOLOGICAL RECORDS
}

\author{
By W. E. Hinds and F. C. Bishopp.
}

Object and application of key. This key is designed to facilitate the arrangement of entomological notes, materials, etc. It is not to be used as are guide cards, but all cards belonging in the key are placed together in front of the note file to show the general plan of arrangement of the notes which follow. Thus one key serves for the entire note system and no repetition is needed for the various species regarding which notes are made.

It is not at all necessary that all notes to be classified according to this key should be prepared in any particular form or kept together in one place. In fact, the key may be applied almost equally well to any notes except those in bound books. No argument is needed as to the many advantages of the modern eard system over the old bound note book system. The size of cards to be used is a matter for personal choice and the only argument for uniformity is that of convenience in filing and handling the notes. In the Cotton Boll Weevil investigation a four by six inch card was found to be most convenient for field notes and therefore adopted for practically all records of the investigation. The cards were prepared by the printer in the 
form of board covered books of fifty sheets each. The leaves were perforated to form the cards as they were removed from the binder.

Notes of any unusual size may be conveniently placed in the file by enclosing them in a manilla envelope of exactly the size of the standard card adopted. Envelope and note are headed alike to insure their identification. Old loose notes may be thus brought into the file with modern cards.

As a matter of convenience we have found it best to place the key on cards. On a card placed in front of the key proper should be given an alphabetical list of the ordinal names adopted or to be followed by the user of the note system. The notes on each order of insects then follow in the sequence indicated on the first card. Under each order the notes are arranged alphabetically by generic names and the species alphabetically under each genus. The notes on a single species are thus brought immediately together under the scientific name of the species. If the common name is more familiar, a cross reference can be made from an alphabetical list of common names. Thus far the arrangement is purely alphabetical, but beyond this point the necessity for some definite method of arrangement arises to enable anyone to find desired notes among a large amount of data and to make the file accessible to and usable by any other than the original maker or filer of the notes.

The key indicates the topical headings to be used and the arrangement to be followed in filing the notes on each and every species alike. It is no longer possible to follow an alphabetical plan and the decimal system used in the Dewey system of library eataloging and in the great work of the Concillium Bibliographicum has therefore been adopted in its principal features. Under each species name, the notes are filed strictly according to the decimal sequence of numbering, except in a few cases where subdivisions can be better arranged alphabetically. In the key a certain decimal number is given to each topic or subject heading, into which the study of the insect may be subdivided and this same subject and decimal number should always be given as the heading on the note to be filed. The statement of both number and subject prevents errors and the misplacement of notes.

Miscellaneous notes or those on undetermined species may be filed temporarily under their accessions number.

The first part of the key applies to general things which assist in systematizing one's work and related records.

Heading of notes. Every note or card should deal preferably with one subject only. The card is given appropriate heading and in de- 
termining this the key is almost indispensable. The upper left-hand corner is always reserved for the decimal number associated with the proper subject. The scientific name of the species considered appears at the top and middle of the card. Below the species name is given the subject heading, locality, date, etc. The author's name should also appear on each note.

The decimal numbering may be conveniently done by a specially constructed rubber stamp made after the manner of the ordinary band dating stamps. This special stamp should have at least six bands, each bearing in vertical line the following fifteen characters as separated by dashes : $1-2-3-4-5-6-7-8-9-0-.,-,-(-)$ Space cannot be taken here for a discussion of the proper use of the comma, colon and parentheses. It is the same as in the Dewey System.

The use of guide cards. In the key itself, guide cards are used for indicating only the primary divisions: Generalia, Work, Life History, etc. It is well to list on the guide card the next series of subdivisional headings occurring under it.

Among the notes to be filed, guide cards should, of course, be used for each species and headed with the names of the order, genus and species. Beyond this the use of guides is purely a matter of personal convenience and the filer may decide for himself whether he cares to give any special significance to the color of card, size of tabs, etc. The guides in no way alter or interfere with the application of the key.

Cross-references. If the subject matter on a card relates to more than one insect, a cross reference card is made and filed under the name of the other species, in the proper decimal sequence of the subject. Similarly, a cross reference is made if the record relates to more than one topic in the study of one species or if the data may have application to more than one topic.

Amplification of key. Throughout the key there is ample room for further development as may be required to adapt it more fully to the study of any new subject and insertions may be made as they are found to be needed. It will be noted that in the series of main divisional numbers, 8 and 9 are unoccupied. In these cases, as in similar ones throughout the key, wherever numbers have been omitted or are unoccupied, there is room for additional subjects of properly coordinated character. Changes may be made to suit the user, either in the wording or character of a subject heading to fit any special need, but if there be room for addition of the needed subjects, it would seem better to add than to substitute. In this way the key is rendered more complete and generally applicable. Inappropriate head- 
ings are simply unused, but remain in the key for the suggestive value they have and for use under species to which they do apply.

Practical usefulness of key. A fairly complete outline of this sort is valuable for its continual suggestion when undertaking the thorough study of any species. With any large volume of notes, particularly relating to one species, some system is indispensable. The key given herewith has been put to thorough test in the large amount of note material accumulated by the numerous agents of the Bureau of Entomology during the six years of the Cotton Boll Weevil investigation. Because of its proven value in this work, it is presented here as a suggestion of the possible divisions in the study of an economic entomological subject and as a practicable means of so arranging the records as to make them at all times easily accessible and completely useful and also because the system seems to be of general applicability in economic entomology.

\section{Key to Classification of Entomological Records}

\section{O Generalia.}

01 Bibliography.

01.1 Indices and references.

01.2 Special literature.

01.3 State laws affecting entomology.

01.31 Quarantine regulations.

01.32 Inspection of nursery stock.

01.8 Literature to secure.

01.9 Miscellaneous literature.

\section{Statistical data.}

02.1 Climatological. (See 44 also.)

02.2 Geological.

02.3 Crop reports.

02.4 Special census reports.

02.5 Special crop statistics.

\section{Clippings.}

03.1 Entomological workers.

03.2 Insect life histories. (See 71 for arrangement.)

03.3 Insect seasonal histories. (See $\mathbf{7 1}$ for arrangement.)

03.4 Insect control, natural.

03.41 Climatological.

03.42 Parasites.

03.43 Predatory enemies.

03.44 Diseases.

03.5 Insect control, artificial.

03.51 Traps.

03.52 Insecticides.

03.521. Stomach poisons. (Arrange alphabetically.)

03.522 Contact insecticides.

03.523 Fumigants.

03.53 Repellents.
O Generalia, Continued.

03 Clippings.

03.54 Machines.

03.55 Treatment of crop after harvesting.

03.56 Restriction of spread.

03.57 Cultural control.

03.6 Distribution.

03.61 Geographical.

03.62 Geological.

\section{Accounts.}

04.1 Appropriations.

04.2 Salaries.

04.3 Equipment.

04.31 Furniture and fixtures.

04.32 Scientific apparatus.

04.33 Tools and machinery.

04.34 Library.

04.35 Live stock.

04.4 Maintenance.

04.41 Supplies.

04.42 Repairs.

04.5 Postage, stationery, etc. 04.51 Postage account.

04.52 Stationery accounts.

04.53 Telegraph accounts.

04.54 Telephone accounts.

04.6 Travel.

04.7 Freight and express.

04.9 Contingent expenses.

\section{Species lists.}

05.1 Economic insects.

05.2 Insects reported during correspondence. 


\section{O Generalia, Continued.}

\section{Host lists.}

06.1 Animal hosts.

06.2 Plant hosts.

\section{Documents.}

o8 Correspondence.

08.1 Special mailing lists.

\section{o9 Miscellaneous.}

09.1 Inventory.

09.2 Common name directory of insects.

\section{Work.}

\section{Work projected.}

10.1 Outlines prepared for projects. 10.2 Forms for tabular records.

\section{Work on hand.}

\section{Questions.}

\section{Instruetions.}

13.1 Forms for uniform note records.

\section{Reports of species, oceurrence} to be investigated.

\section{Methods and apparatus.}

\section{Illustrations.}

18.1 Photography.

18.11 Formulae, tables and method notes.

18.12 Negative catalog. (Arrange alphabetically by subject, referring to consecutive numbers assigned to negatives.)

18.2 Drawings.

18.21 Record of sketches.

18.3 Cuts.

18.31 Catalog of cuts. (Arrange alphabetically by subject, referring to consecutive numbers assigned to cuts and to where cuts have been used.)

19 Reports of completed work.

19.1 Periodical reports of agents.

19.2 Publications listed.

\section{Life History.}

\section{Egg.}

21.1 Description.

21.2 Embryology.

21.5 Duration of stage.

21.6 Hatching.

\section{Larva.}

22.1 Description.

22.2 Anatomy.

22.21 External.

22.22 Internal.
2 Life History, Continued.

22 Iarva.

22.3 Growth.

22.4 Molts.

22.41 Process of molting.

22.42 Effect of food supply upon number of molts.

22.43 Size between molts.

22.5 Duration of stage.

22.6 Pupation.

22.61 Pupal cells.

\section{Pupa.}

23.1 Description.

23.2 Anatomy.

23.5 Duration of stage.

23.6 Transformation.

\section{Adult.}

24.1 Description.

24.2 Period from transformation to emergence.

24.21 Changes before emergence.

24.3 Emergence.

24.31 Changes after emergence.

24.4 Size of adults.

24.41 Dimensions.

24.42 Weights.

24.43 Relation of size to food supply.

24.5 Duration of life.

24.51 Upon buds alone.

24.52 Upon seed pods alone.

24.53 Upon foliage alone.

24.54 Upon sweetened water.

24.55 Without food but with water.

24.56 Without food or water.

24.57 Average length of life, natural condition.

24.58 Hibernated adults without food.

24.6 Sexes.

24.61 Secondary sexual characters.

24.62 Relation of size and color to sex.

24.63 Proportion of sexes.

24.631 In spring.

24.632 In mid-summer.

24.633 In autumn.

24.634 During hibernation.

24.635. Among migrating adults.

24.64 Temperature influence upon sex determination.

24.7 External anatomy.

24.8 Internal anatomy.

24.9 Physiology.

\section{Development.}

25.1 Number of generations. (Localities arranged alphabetically by state and town.)

25.11 Minimam number in season. 


\section{Life History, Continued.}

\section{Development.}

25.12 Maximum number in season.

25.13 Average number in season.

25.2 Temperature influences.

(See 31.12, 31.42 and 44.)

25.21 On activity of adults.

25.22 On rapidity of development.

25.221 During winter.

25.222 During summer.

25.223 Proportion of stages at different periods.

25.23 On sex determination.

25.24 Effective temperature studies.

25.3 Proportion of infested fruit producing adults.

25.5 Duration of life cycle. (Localities arranged alphabetically by state and town.)

25.51 Maximum duration.

25.52 Minimum duration.

25.53 Average duration.

\section{Habits.}

26.1 Food plants. (List by Order, Family, Genus and Species.)

26.11 Portion of plant attacked, and effects.

26.111 Leaf buds.

26.112 Fruit buds.

26.113 Foliage, including petioles.

26.114 Flowers.

26.115 Fruit.

26.116 seed.

26.117 Stem. (Trunk and branches.)

26.118 Bark.

26.119 Root.

26.12 Tests of other plants for food.

26.13 Susceptibility of different varieties of food plants.

26.19 Occurrence on other than food plants.

26.2 Hosts.

26.3 Prey.

26.4 Feeding habits.

26.41 Larval.

26.42 Adult, male.

26.43 Adult, female.

26.44 Both sexes together.

26.45 Feeding on certain plant species.

26.451 Temperature influence on feeding activity. (See 25.2.)

26.452 Feeding activity in different parts of the day.

26.453 Location of food supply by adults.

26.46 Destructive power by feeding. 26.47 Cannibalism. (See 43.)
2 Life History, Continued.

\section{Habits.}

26.48 Predaceous habits.

26.481 Among larvæ.

26.482 Among adults.

26.49 Movement on food plant.

26.491 During day.

26.492 During night.

26.5 Trap foods. (See 51.1 and 51.2.)

26.6 Adaptive capacity.

26.61 To variations in food supply.

26.62 To variations in climatological conditions.

\section{Reproduction.}

27.1 Copulation.

27.11 Age at beginning.

27.12 Attraction between sexes.

27.13 In spring before feeding.

27.14 Duration of copulation.

26.15 Polygamy.

26.16 Polyandry.

27.2 Fertility.

27.21 From a single copulation.

27.22 Parthenogenesis.

24.23 Fertility of hibernated individuals.

27.24 Duration of fertility.

27.3 Oviposition.

27.31 Age at beginning.

27.32 Period between copulation and oviposition.

27.33 Portion of plant chosen for oviposition.

27.331 Leaf buds.

27.332 Fruit buds.

27.333 Foliage, including petiole.

27.334 Flowers.

27.335 Fruit.

27.336 Seed.

27.337 Stem, including trunk and branches.

27.338 Bark.

27.339 Root.

27.34 Miscellaneous places for oviposition.

27.35 The act of oviposition.

27.351 Preliminary examination.

27.352 Formation of cavity.

27.353 Deposition of egg.

27.354 Sealing of cavity.

27.355 Time required to deposit an egg.

27.356 Position of female while ovipositing.

27.357 Activity in ovipositing during different parts of day.

27.358 Stimulation to oviposition by abundance of food supply. 


\section{Life History, Continued.}

\section{Reproduction.}

27.359 Number of eggs deposited.

27.36 Selection of uninfested places for oviposition.

27.37 Dependence of oviposition upon food supply. (See 32.7.)

27.4 Effects of oviposition.

27.41 In various portion of plant species.

27.411 (List as under 26.11.)

27.5 Period of oviposition.

27.51 In hibernated individuals.

27.52 In first generation individuals.

27.53 In individuals of other generations.

27.54 First oviposition in season.

27.55 Last oviposition in season.

27.6 Rate of oviposition.

27.61 Daily rate in laboratory.

27.62 Daily rate in field.

\section{Protection.}

\section{$28.1 \mathrm{Egg}$.}

28.11 When deposited internally. 28.12 When deposited externally. 28.13 By isolation.

28.14 By external structure.

28.15 By protective excretions.

28.2 Larva.

28.21 By place of development.

28.22 By external structure.

28.23 By protective devices.

28.231 By repellent odors.

28.232 By protective constructions.

28.233 By protective excretions.

28.24 By habits.

28.241 Concealment.

28.242 Feigning death.

28.243 Feeding internally.

28.25 By fighting ability.

28.26 By locomotion.

28.261 By flight.

28.262 By running.

28.263 By swimming.

28.29 By coloration.

28.291 Mimicry.

28.292 Warning coloration

28.3 Pupa.

28.31 By place of pupation.

28.32 By molted skins.

28.33 By protective constructions

28.331 Cocoons.

28.332 Earthen cells.

28.333 Leaf rolling.

28.334 Gall formation.

28.39 By coloration.

28.4 Adult.

28.41 By place of transformation.
2 Life History, Continued.

\section{Protection.}

28.42 By external structure.

28.43 By protective devices.

28.431 Repellent odors.

28.432 Protective constructions.

28.433 Protective excretions.

28.44 By habits.

28.441 Concealment.

28.442 Feigning death.

28.443 Feeding internally.

28.49 By coloration.

28.491 Mimicry.

28.492 Warning coloration.

\section{Multiplieation.}

29.1 Annual progeny of one pair. (Theoretical.)

29.2 Number of individuals per acre based upon field counts.

29.3 Relation of multiplication to food supply.

29.4 Restrictions upon multiplication. (See 4 and 5.)

\section{Seasonal History.}

31 Hibernation.

31.1 Entrance into hibernation.

31.11 Time of entrance.

31.12 Temperatures affecting entrance. (See 25.2.)

31.13 Gradual entrance.

31.14 Stages entering hibernation.

31.15 Congregation of individuals preceding entrance into hibernation.

31.16 Mortality occurring at time of entrance into hibernation.

31.17 Activity during hibernation period.

31.2 Shelter during hibernation.

31.21 Apparently favorable conditions.

31.22 Apparently unfavorable conditions.

31.3 Mortality during hibernation.

31.4 Emergence from hibernation.

31.41 Time of emergence.

31.42 Climatic conditions affecting emergence.

31.43 Re-hibernation.

31.44 Number and percentages surviving hibernation.

31.5 Duration of hibernation.

31.51 Localities of observations arranged alphabetically by state and town.

32 Hibernated individuals.

32.1 Finding food supply in spring.

32.11 Distance hibernated individuals will go to food. 


\section{Seasonal History, Continued.}

\section{3o Hibernated individuals.}

32.2 Nature of first food supply.

32.3 Preferred food supply.

32.5 Duration of life of hibernated individuals.

32.6 Movement of hibernated individuals in field before beginning reproduction.

32.7 Oviposition dependent upon food. (See 27.37.)

32.8 Abundance of hibernated individuals.

\section{Progress of infestation.}

33.1 Species injury versus food production.

33.2 Effect of maximum infestation upon species multiplication.

33.3 Proportion of food supply attacked not destroyed.

33.4 Relation of species to crop production.

33.41 Special crop.

33.411 Percentage of crop destroyed.

34 Dispersion, spread of species. (See 63.)

\section{Natural Control.}

41 Mechanical control.

41.1 Resistance to attack of species by normal special plant structures.

41.11 Pilosity of stems.

41.12 Appression of floral envelopes.

41.2 Resistance to species attack by abnormal plant growths.

41.21 By gall formation.

41.22 By proliferation in buds.

41.23 By proliferation in seed pods.

41.24 By proliferation in stem.

41.25 By proliferation in root.

41.26 Influence of locality on proliferation.

41.27 Influence of season on proliferation.

41.28 Influence of variety on proliferation.

41.29 Influence of artificial conditions upon proliferation.

41.291 Cultivation.

41.292 Fertilization.

41.4 Artificial stimulation to proliferation.

41.41 In buds.

41.42 In seed pods.

41.5 Mortality in species due to proliferation.

41.51 In buds.

41.52 In seed pods.
4 Natural Control, Continued.

\section{Mechanical control.}

41.6 Manner in which death is caused by proliferation.

41.7 Rearing stages on prolifid cells as food.

41.8 Proliferation started from other causes than species attack. (Arrange alphabetically.)

41.9 Occurrence of proliferation in other plants than special species. (Arrange alphabetically by order, etc.)

42 Restraint upon species attack by habits of growth of food plant.

42.1 Rapid maturing of fruit.

43 Cannibalism. (See 26.47.)

43.1 Among adults.

43.2 Among larvæ.

44 By climatologieal conditions. (See 02.1.)

44.1 Heat or drying.

44.11 Mortality in picked fresh fruit.

44.111 Buds.

44.112 Flowers.

44.113 Seed pods.

44.12 Mortality in dried hanging fruit.

44.121 Buds.

44.122 Flowers.

44.123 seed pods.

44.13 Mortality in fallen fruit.

44.131 Buds.

44.132 Flowers.

44.133 Seed pods.

44.14 Heat effect upon adults.

44.141 On hot ground.

\subsection{Cold.}

44.21 Effects of frosts.

44.211 Upon food supply.

44.212 Upon life of adults.

44.213 Upon life of immature stages.

44.22 Effect of minimum winter temperatures.

44.221 Upon life of adults.

44.222 Upon life of immature stages.

44.25 Experiments in artificial refrigeration.

44.3 Humidity.

44.31 Drought.

44.32 Excessive humidity.

44.4 Precipitation.

44.41 Precipitation deficient.

44.42 Precipitation excessive. 


\section{Natural Control, Continued.}

\section{By climatologieal conditions.}

44.5 Overflows.

44.51 In summer.

44.52 In winter.

44.55 Experiments in drowning adults, floating.

44.56 Experiments in drowning adults, submerged.

44.57 Experiments in drowning immature stages.

44.58 Experiments in submerging eggs.

\section{Diseases of species.}

45.1 Fungus diseases.

45.2 Bacterial diseases.

\section{Parasites.}

46.1 Breeding of parasite species.

46.11 Species list of primary parasites.

46.111 Parasites of egg.

46.112 Parasites of larva.

46.113 Parasites of pupa.

46.114 Parasites of adult.

46.2 Mortality due to parasites.

46.21 In egg stage.

46.22 In larval stage.

46.23 In pupal stage.

46.24 In adult stage.

(Arrange data by locality and date.)

46.3 Transference of parasites of other insects to species.

46.4 Hyperparasitism.

46.41 Species list.

46.5 Increasing efficiency of parasites.

46.51 Importation of parasites.

46.511 Transference of parasites from one locality to another.

46.512 Introduction of foreign parasites.

46.52 Artificial propagation and distribution.

46.521 On preferred host.

46.522 By securing concentration on desired host by practices affecting multiplication on alternate hosts.

\section{Predatory enemies.}

47.1 Insecta. (Arrange by order, genus, and species alphabetically, as suggested in explanation of key.)

47.2 Arachnida. (Arrange as above.)

47.3 Crustacea. (Arrange as above.)

47.4 Pisces. (Arrange as above.)

47.5 Reptilia. (Arrange as above.)
4 Natural Control, Continued.

47 Predatory enemies.

47.6 Aves. (Arrange as above.)

47.61 Examinations of bird stomachs.

47.7 Mammals. (Arrange as above.)

\section{Artificial Control.}

\section{Traps.}

51.1 Trap foods, unpoisoned.

51.11 Sweets.

51.2 Trap foods, poisoned.

51.3 Trap lights.

51.4 Trap shelters.

51.5 Trap rows.

\section{Insecticides.}

52.1 Stomach poisons. (Arrange alphabetically.) (See 59.41 also.)

52.2 Contact insecticides. (Arrange alphabetically.)

52.3 Fumigants. (Arrange alphabetically.)

52.9 Other insecticides tested. (Arrange alphabetically.)

53 Repellents. (Arrange alphabetically.)

\section{Farm machinery.}

54.1 Special machines for the destruction of pest.

54.2 Attacbments to machinery commonly used in cultivation of crop.

54.3 Machines for aiding in destruction of food supply.

54.4 Improved machines advisable for general farm use.

\section{Treatment of crop after har-} vesting.

55.1 Temporary storage.

55.11 Cold storage.

55.12 Elevators.

55.13 Cellar storage.

55.2 Mechanical treatment of crop.

\section{Restriction of spread.}

56.1 Quarantines.

56.11 Regulations of various states. (Arrange alphabetically.)

56.2 Legislative enactments desirable.

56.3 Restricting of movement of crop within border of infestation.

56.4 Disinfection of shipments to points beyond border of infestation.

56.41 Treatment of crop shipped.

56.42 Treatment of cars used. 


\section{Artificial Control, Continued.}

\section{Restriction of spread.}

56.7 Restriction of multiplication of species.

56.71 Hand picking.

56.711 of insects themselves.

56.712 of infested fruit.

56.72 Burial by cultivation.

56.721 of insects themselves.

56.722 of infested fallen fruit. (See 57.5.)

56.73 Trapping hibernated individuals. (See 51.)

56.74 Destruction of favorable hibernation quarters.

56.75 Proper spacing of rows and plants.

56.76 Fall destruction of food supply. (See 54.3 and 57.7.)

56.77 Rotation of crops. (See 57.9.)

\section{Cultural methods of control.}

57.1 Selection of best seed.

57.2 Thorough preparation of soil.

57.3 Fertilization.

57.4 Early planting or uniform planting.

57.5 Thorough cultivation.

57.6 Early harvesting.

57.7 Early destruction of annual plants.

57.8 Fall breaking of land.

57.9 Rotation of crops.

\section{Experimental farm work.}

59.1 Data regarding locations.

59.11 Alphabetical list of localities arranged by years.

59.12 Alphabetical list of names and addresses of owners and operators of farms.

59.13 Geological conditions represented by farms.

59.14 Climatological conditions represented by farms.

59.15 Proposals for experimental work.

59.16 Contracts for experimental work.

59.2 Data regarding experiments with crops.

59.21 Early planting tests.

59.22 Late planting tests.

59.23 Variety tests.

59.24 Fertilizer tests.

59.25 Cultivation tests.

59.26 Soil tests.

59.27 Isolation tests.
5 Artifical Control, Continued.

\section{Experimental farm work.}

59.3 Data regarding insect conditions. (Arrange by locality alphabetically and chronologically.)

59.4 Data regarding remedial experiments.

59.41 Paris green experiments.

59.411 Applied as dust.

59.412 Applied as spray.

59.45 Cultural remedial experiments.

59.5 Data regarding cultural conditions.

59.51 Preparation of soil.

59.52 Fertilization given.

59.53 Time of planting.

59.54 Cultivation given.

59.55 Destruction of plants.

59.56 Fall treatment of soil.

59.6 Data regarding crop conditions.

59.61 Germination.

59.62 Growth before flowering.

59.63 Flowering.

59.64 Setting of fruit.

59.65 Harvesting.

59.66 Yield.

59.67 Foliage area.

59.68 Number of plants per acre.

59.7 Data regarding climatological conditions.

59.8 Methods commonly used by most successful farmers.

59.81 For special crop. (List by name and address.)

59.9 Data regarding results.

\section{Distribution of Species.}

\section{Geographical distribution.}

61.1 Alphabetical list of recorded localities arranged by the state, county and town.

61.2 Maps showing distribution.

\section{Status of species.}

62.1 Inspection reports.

62.11 Species found present.

62.12 Species not found.

62.2 Special studies of areas of especial abundance of species.

62.3 Special studies of areas of especial scarcity of species.

63 Dispersion (spread) of speeies.

63.1 By natural agencies.

63.11 By flight.

63.111 In spring, seeking food.

63.112 In midsummer.

63.113 In fall. 
6 Distribution of Species, Continued.

63 Dispersion (spread) of species.

63.114 When going into hibernation.

63.115 Seasonal influence upon taking flight.

63.12 By crawling.

63.13 By winds and storms.

63.14 By water along waterways.

63.15 By floods and overflows.

63.16 By artificial carriers, not hosts.

63.17 By movement of hosts as carriers.

63.2 By artificial agencies.

63.21 By shipments of infested materials.

63.22 By movement of containers which have carried infested materials.
6 Distribution of Species, Continued.

63 Dispersion (spread) of species.

63.221 Cars.

63.222 Barrels and other containers.

63.223 Harvesting apparatus.

63.23 By movement of carriers only accidentally related to pest.

63.231 Vehicles passing infested fields or near plants.

\section{Collection.}

71 Classification. (Orders alphabetically.)

72. Accessions catalog.

73 Species catalog.

74 Description list, new species described.

75 Type list and disposition of types.

In discussing the paper Mr. Hunter stated that the system described was a modification of the one used by Mr. Quaintance and was especially valuable in cases where a large amount of data on an insect must be kept so that it can be available for easy reference.

Mr. Felt preferred to use a method that was simpler than the Dewey system, as it took considerable time to train assistants so they could use it to advantage. By means of the system in his office it was impossible to lose any of the note sheets.

Mr. Hart stated that there is little danger of losing sheets or cards. The system in use in Dr. Forbes' office is essentially somewhat similar but not numerical. The great advantage of the system described by Mr. Bishopp is in keeping before the eye the points which should be investigated.

Mr. J. L. Phillips considers the Dewey system a valuable one for arranging correspondence for easy reference. He uses a modification of this system, arranging the counties alphabetically, as well as giving each county and correspondent a number and using decimals to make further sub-divisions for each county. This method is specially valuable where it is necessary to keep in touch with a large number of county inspectors and persons in the inspectors' territory who write about this line of work. Under such a system it is easy to refer at once to the correspondence on this subject with people in any county without going to the card index. All this correspondence can be taken out of the files, examined and returned in a few minutes, while under other systems it would be necessary to keep a cross index, and the cor- 
respondence with any one person would be kept in a separate folder. The method outlined above does not require any extra work and very much less time is needed to refer to the correspondence from any one county. This method presupposes, of course, that carbon copies of letters are filed instead of using the letter book system.

Owing to the lateness of the hour, the meeting adjourned until 9.30 a. m. Saturday, with the understanding that the two papers remaining on the program be read first.

\section{Morning Session, Saturday, December 28, 1907}

Arrangements had been made for a joint meeting of this association and the Association of Horticultural Inspectors and the program had been arranged accordingly. The session was called to order at $9.30 \mathrm{a}$. $\mathrm{m}$. by President Morgan, and the following paper was presented:

\section{BEE DISEASES: A PROBLEM IN ECONOMIC ENTOMOLOGY}

By E. F. Phillips, Washington, D. C.

Bee keeping in the United States is a sole means of livelihood to a comparatively small number of persons, but taken as a whole it forms an industry which commands recognition. Every year the manufacturers of supplies in this country make from $60,000,000$ to $75,000,000$ sections for comb honey and practically all of these are used in the United States. A study of market conditions will reveal the fact that there is three or four times as much extracted honey as comb put on the market, mainly because of the heavy demand for confectionery and baking purposes. A species of insect which forms the basis for an industry adding from $\$ 20,000,000$ to $\$ 25,000,000$ to the resources: of the country annually is well worthy of consideration in economic entomology.

No one conversant with bee keeping conditions would claim that the entire field is now occupied. It is safe to say that many times as: much nectar goes to waste and dries up annually as is gathered by honey bees; probably this country could produce ten times the present yearly honey crop were there more and better bee keepers properly located. In attempting to aid in the building up of this industry, it is necessary to determine the causes which prevent its rapid growth. The two principal causes seem to be too general an ignorance of modern methods of manipulation, and the brood diseases of the bees. The education of all bee keepers to proper methods is no small un- 


\section{$2 \mathrm{BHL}$ Biodiversity Heritage Library}

Hinds, W. E. and Bishopp, F. C. 1908. "A key suggested for the classification of entomological records." Journal of economic entomology 1(2), 91-102. https://doi.org/10.1093/jee/1.2.91.

View This Item Online: https://www.biodiversitylibrary.org/item/37189

DOI: https://doi.org/10.1093/jee/1.2.91

Permalink: https://www.biodiversitylibrary.org/partpdf/325833

\section{Holding Institution}

New York Botanical Garden, LuEsther T. Mertz Library

\section{Sponsored by}

The LuEsther T Mertz Library, the New York Botanical Garden

\section{Copyright \& Reuse}

Copyright Status: NOT_IN_COPYRIGHT

This document was created from content at the Biodiversity Heritage Library, the world's largest open access digital library for biodiversity literature and archives. Visit BHL at https://www.biodiversitylibrary.org. 